\title{
Bio-Oil and Biochar Derived from the Pyrolysis of Palm Kernel Shell for Briquette
} (Minyak Biologi dan Abu Biologi Janaan daripada Pirolisis Isirung Kelapa Sawit untuk Briket)

\author{
NuRhaYATi AbDUllahi, FAUZiah SUlaiman \& AminU AliYU SAFANA*
}

\section{ABSTRACT}

The objective of this study was to produce briquette from the mixture of pyrolysis products. Palm shell was pyrolyzed at a temperature of $400^{\circ} \mathrm{C}$ for $2 \mathrm{~h}$ holding time and heating rate of $10^{\circ} \mathrm{C} / \mathrm{min}$. The biochar and bio-oil ratio was prepared at 3:1 weight percentages for briquette. The viscosity of bio-oil was improved to increase the bonding forces. The characterization of biochar, bio-oil, coal and briquette were analyzed and presented in this study. The density and compressive strength of briquette were, respectively, found to be $0.94 \mathrm{~g} \mathrm{~cm}^{-3}$ and $3.20 \mathrm{Nmm}^{-2}$. The shatter and water resistance of briquette were established to be 97 and $96 \mathrm{wt}$ \% , respectively. The high heating value (HHV) of briquette was $29.6 \mathrm{MJkg}^{-1} \mathrm{greater}$ than that of Malaysian sub-bituminous coal $24.6 \mathrm{MJkg}^{-1}$. It implies that the briquette produced is stable, durable and qualitative. Therefore, it can be concluded that the briquette can substitute coal in some applications.

Keywords: Biochar; bio-oil; briquette; pyrolysis

\section{ABSTRAK}

Objektif kajian ini adalah untuk menghasilkan briket daripada campuran produk pirolisis. Isirung kelapa sawit telah dipirolisis pada suhu $400^{\circ} \mathrm{C}$ selama 2 jam dengan kadar pemanasan $10^{\circ} \mathrm{C} / \mathrm{min}$. Nisbah peratus berat abu dan minyak bagi briket yang terhasil adalah 3:1. Kelikatan minyak bio telah ditambahbaik untuk meningkatkan daya ikatan. Ciri abu, arang batu dan briket telah dianalisis dan dibincang dalam kajian ini. Ketumpatan dan kekuatan mampatan briket adalah $0.94 \mathrm{gcm}^{-3}$ dan $3.20 \mathrm{Nmm}^{-2}$. Rintangan pecahan dan air briket yang tercapai masing-masing adalah 97 and 96 $\%$ bt. Nilai pemanas tinggi (HHV) briket adalah $29.6 \mathrm{MJkg}^{-1}$ dan lebih tinggi daripada arang batu bitumen Malaysia, iaitu 24.6 $\mathrm{MJkg}^{-1}$. Ini menunjukkan bahawa briket yang terhasil adalah stabil dan tahan lama. Kesimpulannya, briket yang terhasil boleh menggantikan arang batu dalam kegunaan tertentu.

Kata kunci: Abu biologi; briket; minyak biologi; pirolisis

\section{INTRODUCTION}

The International Energy Agency (IEA) Statistics in the year 2005 reported that biomass contributed to about $10 \%$ of primary energy demand globally (Chen et al. 2011). Malaysia, Indonesia and Nigeria generate an extensive amount of biomass from palm oil residues (Sumathi \& Mohamed 2008). These biomasses are suitable fuels in the form of pellets and briquettes (Lam et al. 2015). Briquettes are made using densification of predominantly biomass. Briquettes are used for cooking, heating and other industrial applications (Shyamalee \& Senanayaka 2015). The physical properties such as density, moisture, binder, particle size and compressive strength are best parameters that decide the briquette quality (Kaliyan \& Vance 2009; Kask et al. 2010).

Pyrolysis product (biochar and bio-oil) have many applications (Aziz et al. 2013). However, factors, such as high water and ash contents, instability, high corrosiveness, low heating value and high viscosity restrict the utilization of bio-oil. Therefore, improving the bio-oil becomes inevitable to increase its quality (Xiu \& Shahbazi 2012). Several studies have been conducted on the densification of biomass residues. Nevertheless, there are few studies on the briquette generation from pyrolyzed biomass which have HHV preferably over raw biomass. Hence, this study is expected to produce and analyzed briquette from the mixture of bio-oil and biochar.

\section{MATERIALS AND METHODS}

\section{SAMPLE COLLECTION AND PREPARATION}

The palm shell sample was obtained from Oil Palm Industry at Nibong Tebal, Pulau Pinang, Malaysia. The sample received was relatively in a dry condition, yet it was dried to eliminate moisture in the oven for $24 \mathrm{~h}$ at $105^{\circ} \mathrm{C}$. Sago starch used was obtained from MYDIN shopping mall located at Bukit Janbul, Pulau Pinang, Malaysia. The pyrolysis experiment was carried out at a temperature of $400^{\circ} \mathrm{C}$, at a constant heating rate of $10^{\circ} \mathrm{C} /$ min and holding time of $2 \mathrm{~h}$. The pyrolyzer temperature was monitored using a K-type thermocouple. Biochar residue and bio-oil were collected, measured and stored, while non-condensable gas was calculated from the difference. During the experiment, $2 \mathrm{~L} / \mathrm{min}$ of nitrogen was circulated inside the pyrolyzer. The bio-oil and sago starch powder 
was blended in the proportion of $4: 1$ in a container and warmed at a temperature of $105^{\circ} \mathrm{C}$ for $3 \mathrm{~h}$ and $130^{\circ} \mathrm{C}$ for 2 $\mathrm{h}$, separately. It was led to enhance the viscosity of bio-oil and increment of the holding forces as a binder.

\section{BRIQUETTES PRODUCTION}

The mixture of biochar and bio-oil was prepared in the ratio of 3:1 weight percentages. The mixture was allowed to dry for $20 \mathrm{~min}$ at room temperature before feeding into mold and press. The cylindrical briquette mold used had an inner diameter of $19.4 \mathrm{~mm}$ and a height of $50.2 \mathrm{~mm}$. The manual hydraulic pressing machine (briquette machine) used has a maximum pressuring capacity of $1000 \mathrm{kgcm}^{-2}$. For each briquette made about 10-20 g of the mixture was filled into a mold and compressed at $150 \mathrm{kgcm}^{-2}$ for $2 \mathrm{~min}$. The weight of briquette produced was recorded instantly and placed under ambient conditions for about 10 days to dry. Figure 1 illustrates the schematic briquette machine.

\section{CHARACTERIZATION}

Thermogravimetric analysis (TGA) was performed on biomass. It was perform using model Perkin Elmer STA 6000 thermogravimetric analyzer. The analysis was carried out in the presence of nitrogen $\left(\mathrm{N}_{2}\right)$ gas flow under $5^{\circ} \mathrm{C} /$ min heating rate, a sample size of $250-355 \mu \mathrm{m}$ and the sample were heated from ambient temperature to about $900^{\circ} \mathrm{C}$. The lignocellulosic analysis was conducted using different ASTM methods. The percentage of hemicelluloses was determined from the difference between holocellulose and alpha-cellulose percentage. Proximate analysis was performed according to ASTM E871 for moisture content, ASTM E872 for volatile matter and ASTM E1755-01 for ash content. Whereby, the difference determined fixed carbon.

Elemental analysis was conducted to analyze the proportion of carbon $(\mathrm{C})$, hydrogen $(\mathrm{H})$, nitrogen $(\mathrm{N})$, sulphur $(\mathrm{S})$ and oxygen $(\mathrm{O})$. The elemental analysis was performed using Perkin Elmer 2400 analyzer, 2- $2.8 \mathrm{mg}$ of sample was used to measure the percentage weight of each element present. The HHV was determined using a bomb calorimeter system IKA C 200, oxygen station C248 with an empty water hose. For each test run, 0.5 to $0.8 \mathrm{~g}$ of the sample was measured and placed in the crucible joined to the thread from the ignition wire, closed and oxygen gas was pumped. However, the lower heating value (LHV) was calculated using HHV and hydrogen $(\mathrm{H}$ in wt. \%) content measured as shown in equation (1) (Adisak 2006). LHV is important than $\mathrm{HHV}$, attributable to the fact that LHV does not have any input from the latent heat of the vapor (Uemura et al. 2011).

$$
\mathrm{LHV}_{\mathrm{dry}}(\mathrm{MJkg}-1)=\mathrm{JJV}_{\mathrm{dry}}-2.442\left(\frac{8.936 \mathrm{H}}{100}\right)
$$

\section{BIO-OIL CHARACTERIZATION}

The water content of the bio-oils was determined using Karl Fischer Titration, (870 KF Titrino Plus) water determination. The bio-oils were initially titrated with standard Karl Fischer reagent to an electrometric end point. The liquid sample is drawn off in a dry syringe and injected into the titration vessel and titrated. A Fisher Scientific Accumet AB15/15+ pH meter made from Singapore was used to determine the $\mathrm{pH}$ value of the bio-oils. The bio-oil sample was placed into a beaker; electrode and temperature probe was immersed into the sample solution.

The viscosity of bio-oils was determined using portable Rion viscometer (VT-03/04). The viscometer used has a capacity to measure thickness between 15 and 150 cP. About $120 \mathrm{~mL}$ of bio-oil was measured at $25^{\circ} \mathrm{C}$ and placed in the cup to its edge. The densities of bio-oils were measured at a room temperature $\left(25^{\circ} \mathrm{C}\right)$ using Portable Density Meter, DMA 35 Portable Density/Specific Gravity/ Concentration Meter. A temperature sensor measures the temperature of the sample right at the measuring cell.

\section{BRIQUETTE CHARACTERIZATION}

The water absorption test was conducted by immersing briquette into a beaker filled with cold tap water for $5 \mathrm{~min}$ at room temperature $\left(25^{\circ} \mathrm{C}\right)$. The weights of the briquettes and beaker were measured before and after immersing. The difference in weight of the briquette before and after immersing determines the water absorbed during the $5 \mathrm{~min}$ test. This procedure was adopted with some modification from Kaliyan and Vance (2009). The compressive strength

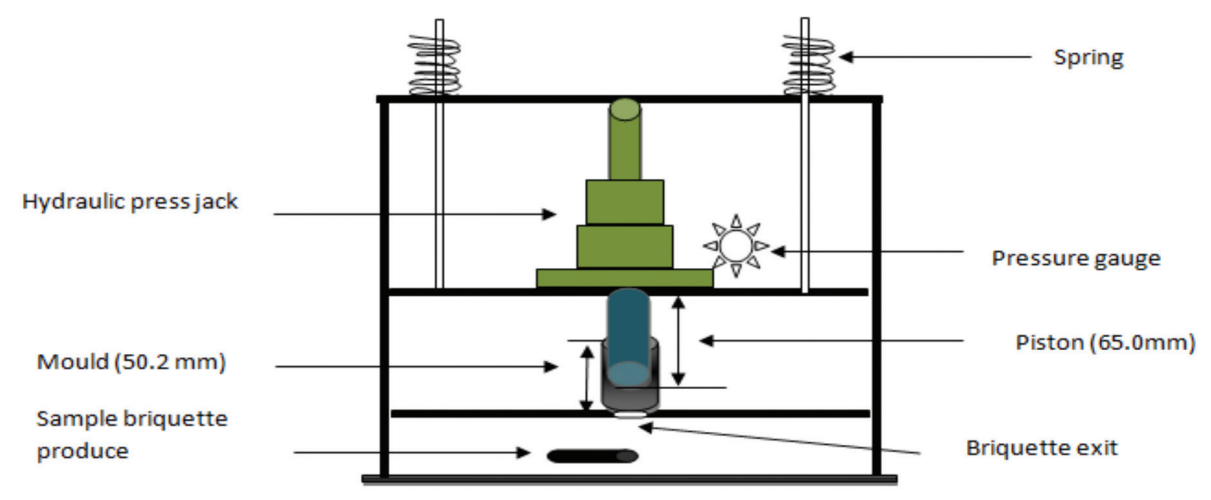

FIGURE 1. A schematic briquetting machine 
test was conducted using Testometric M350 - $10 \mathrm{kN}, 2 \mathrm{MSB}$ Tensile Test with a capacity of $1000 \mathrm{~N}$ loads and height of $500 \mathrm{~mm}$. Briquette assessed is positioned straight in the compression chamber, and an increasing load was applied at a steady rate of $50 \mathrm{~mm} / \mathrm{min}$ until the briquette failed by crashing. The greatest load to cause a crash of briquette was read on the screen of a computer connected to the Testometric machine. Finally, the compressive strength was calculated using (2) (Suparin 2007).

$$
\text { Compressive strength }=\frac{\text { Load at briquette failure }(\mathrm{N})}{\text { Cross sectional area of Briquette }(\mathrm{mm} 2)}
$$

The shatter index test (shatter resistance), briquette sample was permitted to drop from a standard height of $2 \mathrm{~m}$ onto a metal base for twelve times and the portion of the briquette remains was measured. The shatter index was calculated as the ratio of the weight of briquette remained after dropping to the initial weight of briquettes before dropping as given by the following equation.

$$
\text { Shatter index }=\frac{\text { Weight of briquette remained after dropping }}{\text { Weight of briquette before dropping }}
$$

To determine the density $(\rho)$ of briquette the mass (m) of briquette was measured using a digital weighing balance and volume (v) was calculated using an average diameter and height of the briquette which was taken using Vanier caliper. This procedure was adopted with modification from Tembe and Ekhuemelo (2014).

$$
\rho=\frac{\mathrm{m}}{\mathrm{v}}
$$

\section{RESULTS AND DISCUSSION}

\section{PALM SHELL CHARACTERISTICS}

The contents of cellulose, hemicelluloses and lignin for the shell are shown in Table 1 along with other literature results. The percentage compositions of lignocellulosic play a vital role in the pyrolysis products. Figure 2 shows the DTG and TGA bends. The crest on DTG around 30 to $100^{\circ} \mathrm{C}$ is related with the evaporation of moisture and extractives which indicate the first weight reduction for the palm shell. The comparable perception was accounted for by Idris et al. (2012) on a similar oil palm biomass. The crests over $100^{\circ} \mathrm{C}$ were accordingly deterioration of hemicelluloses and cellulose, separately. Though, some piece of lignin may begin to deteriorate in this district. Standardized annotation was declared by Baroni et al. (2016). The disintegration around $400^{\circ} \mathrm{C}$ indicates a continuation of other stable lignin compounds and recombining responses between solid, liquid and vaporous products. Sulaiman and Abdullah (2011) detailed that DTG bends for shell and fiber accomplished isolate crests for hemicellulose at around $300^{\circ} \mathrm{C}$ and cellulose over $300^{\circ} \mathrm{C}$. It can be seen that from the DTG curve, the decadence of lignin outstripped temperature above $600^{\circ} \mathrm{C}$. Lignin decay holds at a higher temperature more than $500^{\circ} \mathrm{C}$ (Baroni et al. 2016).

TABLE 1. The lignocellulosic compositions

\begin{tabular}{lccc}
\hline Components (wt. \%) & Shell & Literature & Reference \\
\hline Cellulose & 20.7 & 20.8 & Abnisa et al. (2013)a \\
Hemicellulose & 23.3 & 22.7 & Abnisa et al. (2013)b \\
Lignin & 49.5 & 50.7 & Uemura et al. (2011) \\
Extractives & 6.5 & 4.8 & Kong et al. (2014) \\
Ash & ---- & 1.0 & Kong et al. (2014) \\
\hline
\end{tabular}

Weight percentage dry basis (wt. \%)

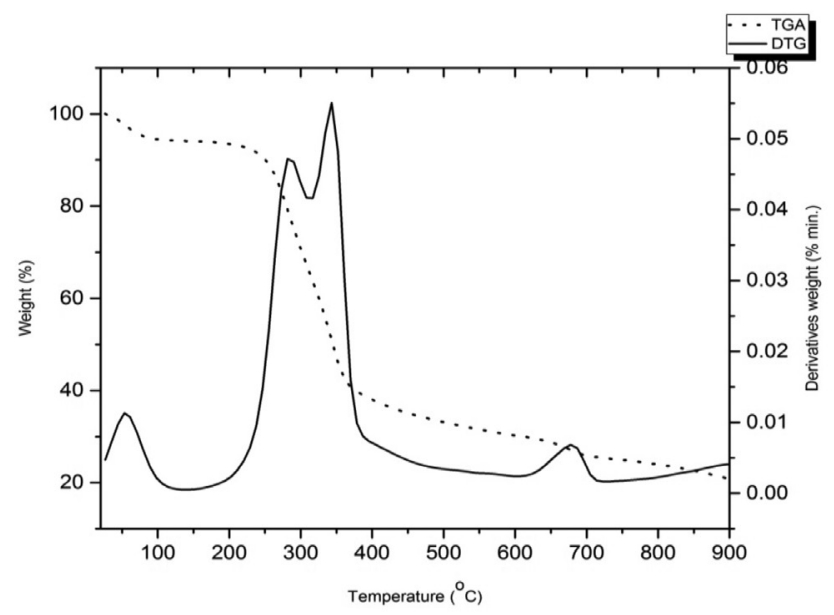

FIGURE 2. TGA and DTG curves for palm shell 


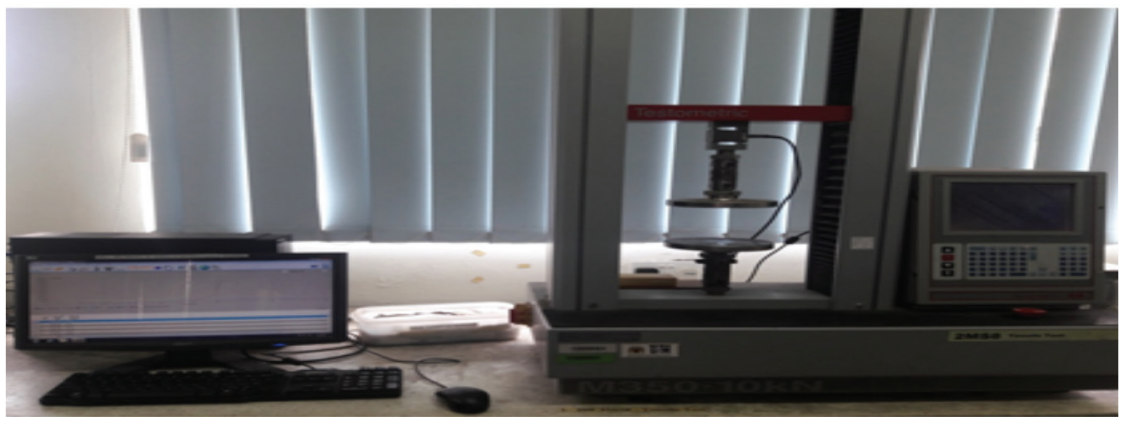

FIGURE 3. Testometric machine

The percentage of volatile matter, fixed carbon, ash content and moisture are reasonable parameters of pyrolysis product yields. Table 2 shows the results obtained from the proximate, elemental, LHV and HHV of shell and sago. Sago starch had 44.7 wt. \% carbon, 48.50 wt. \% oxygen, $6.50 \mathrm{wt}$. $\%$ and 0.25 wt. $\%$ nitrogen. However, the molecular formula can be written as $\mathrm{CH}_{1.73} \mathrm{O}_{0.81}$. The HHV and LHV were found to be $14.65 \mathrm{MJkg}^{-1}$ and 13.23 $\mathrm{MJkg}^{-1}$, respectively.

\section{BIOCHAR AND BRIQUETTE CHARACTERISTICS}

The volatile matter, ash and fixed carbon contents were observed to be individually $49.7 \mathrm{wt} . \%, 8.5 \mathrm{wt} . \%$ and 41.8 wt. $\%$ for biochar and 55.95 wt. $\%, 4.83$ wt. $\%$ and 39.22 wt. $\%$ for briquette (Table 2). Briquette produced had an HHV of $29.6 \mathrm{MJkg}^{-1}$ more than that of biochar and Malaysian sub-bituminous coal (24.6 $\left.\mathrm{MJkg}^{-1}\right)$. The carbon and oxygen contents for biochar and briquette were observed to be 61.02 and $32.96 \mathrm{wt} . \%$ and 63.3 and $32.38 \mathrm{wt} . \%$, respectively. The content of hydrogen and nitrogen were found to be 5.21 and $0.81 \mathrm{wt}$. \% for biochar and 3.4 and 0.92 wt. $\%$ for briquette, individually. In comparison, briquette had a high HHV than biochar and coal which could be related to the bio-oil content in the briquette. The fundamental role of biomass briquettes is to substitute coal use for power generation. Briquettes are used for firing use in brick kilns, in cement industries and as a fuel for boilers (Abhishek 2014).

The density, compressive strength, shatter resistance and water resistance of briquette were presented in Table 3 . The density and compressive strength were found to be $0.94 \mathrm{gcm}^{-3}$ and $3.20 \mathrm{Nmm}^{-2}$, respectively. Comparably, the average density and compressive strength of briquette obtained from Newspaper waste were reported to be $0.2898 \mathrm{gcm}^{-3}$ and 0.124 to $0.238 \mathrm{Nmm}^{-2}$ (Shyamalee \& Senanayaka 2015). The shatter resistance depends on the type of binder use in the briquette. The shatter resistance of briquette discovered in this study was about $97 \mathrm{wt}$ \% and weight loss in the number of pieces was $3 \mathrm{wt} \%$. However, these do not guarantee the production of failure free briquettes, the weight, height and some drops could be factors that can regulate the failure of briquettes during the shatter resistance test. The stronger the briquette the little number of pieces found after dropping (Ward 2013). These indicated that the briquette produced in this study from the mixture of biochar and bio-oil is stable and durable. Bazargan et al. (2014) reported that the impact resistance (shatter resistance) of briquettes produced from the compaction of PKS biochar, water and starch as a binder in the ratio of 70:20:10 do not break instantly. There was $5 \%$ loss of sample mass in the form of dust

TABLE 2. Physical and chemical analysis

\begin{tabular}{|c|c|c|c|c|c|}
\hline Materials (wt. \%) & Sago & Shell & Biochar & Briquette & Coal (Idris et al. 2012) \\
\hline \multicolumn{6}{|l|}{ Proximate analysis ${ }^{\mathrm{a}}$} \\
\hline Moisture content & 3.29 & 4.7 & 3.7 & 1.75 & -- \\
\hline Volatile matter & 79.47 & 75.4 & 49.7 & 55.95 & 42.64 \\
\hline Ash content & 2.21 & 8.7 & 8.5 & 4.83 & 3.45 \\
\hline Fixed carbon ${ }^{\mathrm{b}}$ & 15.03 & 15.9 & 41.8 & 39.22 & 53.94 \\
\hline \multicolumn{6}{|l|}{ Chemical analysis ${ }^{\mathrm{a}}$} \\
\hline Carbon & 44.75 & 50.29 & 61.02 & 63.3 & 60.04 \\
\hline Hydrogen & 6.5 & 6.34 & 5.21 & 3.4 & 5.05 \\
\hline Nitrogen & 0.25 & 0.47 & 0.81 & 0.92 & 1.93 \\
\hline Oxygen $^{\mathrm{b}}$ & 48.5 & 42.81 & 32.96 & 32.38 & 32.62 \\
\hline \multicolumn{6}{|l|}{ Calorific $\left(\mathrm{MJkg}^{-1}\right)$} \\
\hline HHV & 14.65 & 19.5 & 26.9 & 29.6 & 24.6 \\
\hline LHV & 13.23 & 18.12 & 25.8 & 28.7 & -- \\
\hline
\end{tabular}

${ }^{a}$ weight percentage (wt. \%), ${ }^{\text {c}}$ calculated by difference 
TABLE 3. Properties of briquette

\begin{tabular}{lc}
\hline Properties & Briquette \\
\hline Water resistance (wt. \%) & 96 \\
Density $\left(\mathrm{gcm}^{-3}\right)$ & 0.94 \\
Shatter resistance (wt. \%) & 97 \\
Compressive strength $\left(\mathrm{Nmm}^{-2}\right)$ & 3.2 \\
\hline
\end{tabular}

and small pieces during the third drops. However, after 10 drops, there were about $10 \%$ pieces of briquettes mass.

The water resistance test conducted in this study showed that the weight percentage of briquette is increased by $4 \mathrm{wt}$ \% after immersed into cold water for $5 \mathrm{~min}$. A fluid vesicle was instantly observed after sinking of briquettes and ultimately vanished after few second the fluid vesicle could be accountable for the $4 \mathrm{wt}$. \% increase. It implies that the water resistance of briquette is 96 wt. \%.

\section{BIO-OIL CHARACTERISTICS}

The chemical composition and calorific values for biooils with and without sago were presented in Table 4. It was discovered that the carbon, hydrogen, nitrogen and oxygen contents were $15.75,8.53,0.71$ and $75.01 \mathrm{wt}$. \% for bio-oil without sago and 37.87, 9.89, 0.69 and 51.55 wt. \% for bio-oil with sago, respectively. The HHV was found to be $19.11 \mathrm{MJkg}^{-1}$ for bio-oil without sago and 21.23 $\mathrm{MJkg}^{-1}$ for bio-oil with sago, respectively. The water content was determined to be low in bio-oil with sago. By implication, the addition of starch additives in the bio-oil reduced the water content and consequently ameliorates the calorific value of the bio-oil. The viscosity, density and $\mathrm{pH}$ of bio-oils were also shown in Table 4. The densities were found to be 1.432 and 1.038 $\mathrm{gcm}^{-3}$ for the bio-oils with and without sago, respectively. Abdullah and Gerhauser (2008) described bio-oil as a highly dense liquid with a density around $1.2 \mathrm{gcm}^{-3}$. The $\mathrm{pH}$ values for bio-oil with and without sago were 4.68 and 2.51, respectively. Sukiran and Bakar (2009) studied properties of bio-oil obtained from pyrolysis of $\mathrm{EFB}$ at a temperature of $400^{\circ} \mathrm{C}$ and heating rate of $30^{\circ} \mathrm{C}$. They reported that the density, heating value, $\mathrm{pH}$, carbon, hydrogen, nitrogen and oxygen contents were $1 \mathrm{gcm}^{-3}$, $20.23 \mathrm{MJkg}^{-1}, 3.40,35.29$ wt. \%, 6.67 wt. \%, 1.02 wt. \% and 57.02 wt. \%, respectively. Aziz et al. (2013) reported the $\mathrm{pH}$ value of palm shell bio-oils was between 2.9 and 3.3. They, however, highlighted that the $\mathrm{pH}$ value of biooil was incomparable to commercial diesel because of the presence of organic acids in the bio-oils.

The viscosities of bio-oil as shown in Table 4 were found to be $2.1 \mathrm{cP}$ for bio-oil without sago and $47.2 \mathrm{cP}$ for bio-oil with sago, respectively. The viscosity of bio-oil is comparatively higher than that of other liquids fuels such as diesel and gasoline (Thangalazhy-Gopakumar et al. 2010).
TABLE 4. Physical and chemical properties of bio-oil

\begin{tabular}{lcc}
\hline Properties & $\begin{array}{c}\text { Bio-oil without } \\
\text { sago }\end{array}$ & $\begin{array}{c}\text { Bio-oil with } \\
\text { sago }\end{array}$ \\
\hline Water content $(\%)$ & 39 & 14 \\
Viscosity cP $\left(25^{\circ} \mathrm{C}\right)$ & 2.1 & 47.2 \\
Density $25^{\circ} \mathrm{C}\left(\mathrm{gcm}^{-3}\right)$ & 1.038 & 1.432 \\
pH & 2.51 & 4.68 \\
Carbon & 15.75 & 37.87 \\
Hydrogen & 8.53 & 9.89 \\
Nitrogen & 0.71 & 0.69 \\
Oxygen & 75.01 & 51.55 \\
& & \\
HHV $\left(\mathrm{MJkg}^{-1}\right)$ & 19.11 & 21.23 \\
LHV $\left(\mathrm{MJkg}^{-1}\right)$ & 17.2 & 19.1 \\
\hline
\end{tabular}

\section{CONCLUSION}

This research uncovered that biomass pyrolysis product (biochar and bio-oil) can also be utilized for briquette production. The density and compressive strength of briquette were respectively found to be $0.94 \mathrm{gcm}^{-3}$ and $3.20 \mathrm{Nmm}^{-2}$. The shatter and water resistance of briquette were established to be 97 and $96 \mathrm{wt} \%$, respectively. The HHV of briquette was $29.6 \mathrm{MJkg}^{-1}$ greater than that of Malaysian sub-bituminous coal $24.6 \mathrm{MJkg}^{-1}$. It is additionally demonstrated that the briquette from the blend of biochar and bio-oil are qualitative, stable and durable. The briquette produced can substitute coal in a few applications. Notwithstanding, the bio-oil alone cannot be utilized as a binder given high water content. The bio-oil content in the briquette enhanced the heating value of briquette when compared with the initial heating value of biochar.

\section{ACKNOWLEDGEMENTS}

The authors wish to express their appreciation to the Universiti Sains Malaysia for the financial support through grants RUI [1001/PFIZIK/814250] and [1001/ PFIZIK/814228]. My much gratitude goes to Federal University Dutse, Nigeria for giving me the chance to study at Universiti Sains Malaysia.

\section{REFERENCES}

Abdullah, N. \& Gerhauser, H. 2008. Bio-oil derived from empty fruit bunches. Fuel 87(12): 2606-2613.

Adisak, P., James, O.T. \& Anthony, V.B. 2006. Fast pyrolysis of agricultural residues from cassava plantation for bio-oil production. Paper presented at the 2nd Joint International Conference on Sustainable Energy and Environment. Bangkok, Thailand. November 21-23.

Abnisa, F., Arami-Niya, A., Wan, D. \& Sahu, J.N. 2013a. Characterization of bio-oil and bio-char from pyrolysis of palm oil wastes. BioEnergy Research 6(2): 830-840.

Abnisa, F., Arami-Niya, A., Wan, D., Sahu, J.N. \& Noor, I.M. 2013b. Utilization of oil palm tree residues to produce bio-oil and bio-char via pyrolysis. Energy Conversion and Management 76: 1073-1082. 
Aziz, S.M.A., Rafeah, W., Zainab, N. \& Sinin, H. 2013. Biooils from microwave pyrolysis of agricultural wastes. Fuel Processing Technology 106: 744-750.

Baroni, E.D., Tannous, K., Rueda-Ordonez, Y.J. \& TinocoNavarro, L.K. 2016. The applicability of isoconversional models in estimating the kinetic parameters of biomass pyrolysis. Journal of Thermal Analysis and Calorimetry 123(2): 909-917.

Bazargan, A., Rough, S.L. \& Mckay, G. 2014. Compaction of palm kernel shell biochars for application as solid fuel. Biomass and Bioenergy 70: 489-497.

Chen, W.H., Cheng, W.Y., Lu, K.M. \& Huang, Y.P. 2011. An evaluation on improvement of pulverized biomass property for solid fuel through torrefaction. Applied Energy 88(11): 3636-3644.

Idris, S.S., Norazah, A.R. \& Khudzir, I. 2012. Combustion characteristics of Malaysian oil palm biomass, sub-bituminous coal and their respective blends via thermogravimetric analysis (TGA). Bioresource Technology 123: 581-591.

Kaliyan, N. \& Vance, R.M. 2009. Factors affecting strength and durability of densified biomass products. Biomass and Bioenergy 33(3): 337-359.

Kask, Ü., Šooš, L., Križan, P., Laurmaa, V., Aruniit, A., Kulu, P. \& Kers, J. 2010. Determination of physical, mechanical and burning characteristics of polymeric waste material briquettes. Estonian Journal of Engineering 16(4): 307-316.

Lam, P.S., Pak, Y.L., Shahab, S., Jim, L., Xiaotao, T.B., James, D.S., Amadeus, P. \& Warren, E.M. 2015. Steam explosion of oil palm residues for the production of durable pellets. Applied Energy 141: 160-166.

Shyamalee, D., Amarasinghe, A.D.U.S. \& Senanayaka, N.S. 2015. Evaluation of different binding materials in forming biomass briquettes with saw dust. International Journal of Scientific and Research Publications 5: 1-8.

Sukiran, M.A., Chin, C.M. \& Bakar, N.K.A. 2009. Bio-oils from pyrolysis of oil palm empty fruit bunches. American Journal of Applied Sciences 6(5): 869-875.

Sulaiman, F. \& Abdullah, N. 2011. Optimum conditions for maximising pyrolysis liquids of oil palm empty fruit bunches. Energy 36(5): 2352-2359.
Sumathi, S., Chai, S.P. \& Mohamed,A.R. 2008. Utilization of oil palm as a source of renewable energy in Malaysia. Renewable and Sustainable Energy Reviews 12(9): 2404-2421.

Suparin, C., Suwit, S. \& Prattana, K. 2007. Development of fuel briquettes from biomass-lignite blends. Journal Science 35(1): 43-50.

Tembe, E.T., Otache, P.O. \& Ekhuemelo, D.O. 2014. Density, shatter index and combustion properties of briquettes produced from groundnut shells, rice husks and saw dust of Daniellia oliveri. Journal of Applied Biosciences 82(1): 7372-7378.

Thangalazhy-Gopakumar, S., Sushil, A., Harideepan, R., Ram, B.G., Oladiran, F., Maobing, T. \& Sandun, D.F. 2010. Physiochemical properties of bio-oil produced at various temperatures from pine wood using an auger reactor. Bioresource Technology 101(21): 8389-8395.

Uemura, Y., Wissam, N.O., Toshio, T. \& Suzana, B.Y. 2011. Torrefaction of oil palm wastes. Fuel 90(8): 2585-2591.

Ward, B .J. 2013. Human fecal biochar briquettes from the sol-char toilet for use as a solid fuel in the developing world. Master Thesis. University of Colorado at Boulder (unpublished).

Xiu, S. \& Abolghasem S. 2012. Bio-oil production and upgrading research: A review. Renewable and Sustainable Energy Reviews 16(7): 4406-4414.

Nurhayati Abdullah, Fauziah Sulaiman \& Aminu Aliyu Safan* Universiti Sains Malaysia

11800 USM Penang, Pulau Pinang

Malaysia

Aminu Aliyu Safan*

Department of Physics, Federal University Dutes (FUD)

Nigeria

*Corresponding author; email: basalihe2@gmail.com

Received: 8 March 2017

Accepted: 4 May 2017 